\begin{tabular}{lcccr} 
T H E & A R C H I V E & O F & M E C H A N I C A L & E N G I N E E R I N G \\
\hline VOL. LVIII & 2011 & Number 4
\end{tabular}

10.2478/v10180-011-0026-2

Key words: thoracic-lumbar spine segment, vertebra compressive fracture, computer tomography (CT), virtual 3D-CAD model, rapid prototyping (RP), material model

\title{
VIRTUAL AND MATERIAL MODELS OF HUMAN \\ THORACIC-LUMBAR SPINE WITH COMPRESSIVE FRACTURE BASED ON PATIENTS' CT DATA AND THE RAPID PROTOTYPING TECHNIQUE
}

\begin{abstract}
The paper presents the development procedures for both virtual 3D-CAD and material models of fractured segments of human spine formulated with the use of computer tomography (CT) and rapid prototyping (RP) technique. The research is a part of the project within the framework of which a database is developed, comprising both 3D-CAD and material models of segments of thoracic-lumbar spine in which one vertebrae is subjected to compressive fracture for a selected type of clinical cases. The project is devoted to relocation and stabilisation procedures of fractured vertebrae made with the use of ligamentotaxis method. The paper presents models developed for five patients and, for comparison purposes, one for a normal spine. The RP material models have been built basing on the corresponding 3D-CAD ones with the use of fused deposition modelling (FDM) technology. 3D imaging of spine segments in terms of 3D-CAD and material models allows for the analysis of bone structures, classification of clinical cases and provides the surgeons with the data helpful in choosing the proper way of treatment. The application of the developed models to numerical and experimental simulations of relocation procedure of fractured vertebra is planned.
\end{abstract}

\section{Introduction}

The methods for processing medical images when building 3D-CAD models [33] and material models using the rapid prototyping (RP) techniques [2], [6], [7], [16], [17] have become more and more commonly applied in the

* Institute of Mechanics and Printing, Warsaw University of Technology, 85 Narbutta, Warsaw02-524, Poland; E-mail: a.dabrowska.tkaczyk@gmail.com, floran@wp.pl, roman.grygoruk@gmail.com, kskalski@wip.pw.edu.pl

** Department of Materials and Biomedical Engineering, Bialystok University of Technology, 45a Wiejska, Bialystok 15-351, Poland; E-mail: piotr.borkowski@pb.edu.pl 
426 ANNA DĄBROWSKA-TKACZYK, ANNA FLORIAŃCZYK, ROMAN GRYGORUK, KONSTANTY SKALSKI, PIOTR BORKOWSKI

process of preoperative planning to visualisation of the bone structures to be operated [4], [28], [29], [30]. In the case of relocation procedure by reposition of a vertebrae after compression fracture made with the use of ligamentotaxis method [13], [19], [24], the visualisation of geometry and bone fragment positions relative to each other is of crucial importance. The geometrical reconstruction of neighbouring vertebrae, into which the transpedicular screws are implanted, is also essential. Improper screw implantation through the arc pedicle (insertion outside the vertebral body, perforation of the internal wall and penetration into the spinal canal) may result in serious clinical complications [1], [15], [18], [20], [31]. The aforementioned comments are well justified by clinical practise and the results we have obtained from the experiments performed on the animal spine [9], [13].

Upon processing the CT data with the use of special software [36] one can extract effectively from images bone tissues area to develop 3D-CAD models of damaged spine fragments. The obtained 3D-CAD virtual models followed by further processing [36] upon application of RP model preparing software [35] create the basis for material models built by means of RP technique [37]. The subject of the paper consist in defining the technological procedures for building the models described above together with their applications. Upon completing successfully the above tasks, one can perform numerical and experimental simulation of surgical procedures of damaged spinal segments using the reliable patient's CT data.

\section{Materials and methods}

There are several criterions according to which clinical cases of vertebra compression fractures can be classified [14], [18], [21], [22]. To build $3 \mathrm{D}-\mathrm{CAD}$ virtual and material models of damaged spinal segments, the clinical data of five patients with flexion-rotation fractures (unstable) of vertebra in the thoracic-lumbar fragments were selected. The CT technique is the most accurate method when applied to mapping of bone structures [8]. CT data are saved in the DICOM format [33]. The data processing is a multi-stage procedure shown in Figs. 1, 2. First, bone structure of the spine fragment to be considered should be identified and highlighted. That stage is crucial for the whole modelling procedure and depends strongly on parameters specified in the course of CT data gathering. The parameters of CT tests, mainly a thickness of a scan layer and a distance between the subsequent layers, affect the quality of the resulting model. The identification and mapping of real shape of the bone segment becomes more difficult as the distance between the scanned layers increases. On the other hand, the increase in number of scanned layers in the considered segment results in more precise determi- 
nation of positions and shapes of the bone fragments in damaged vertebra, on the other hand, it poses an additional risk to a patient due to increased radiation dose. The standard $\mathrm{CT}$ data parameters determined by radiologists to be used by orthopaedic surgeons were employed for the purposes of the paper. Those were the clinical data on patients of the Military Medical Institute (WIM) in Warsaw. According to Polish binding regulations, the CT data transfer was agreed by the Bioethical Committee of WIM.

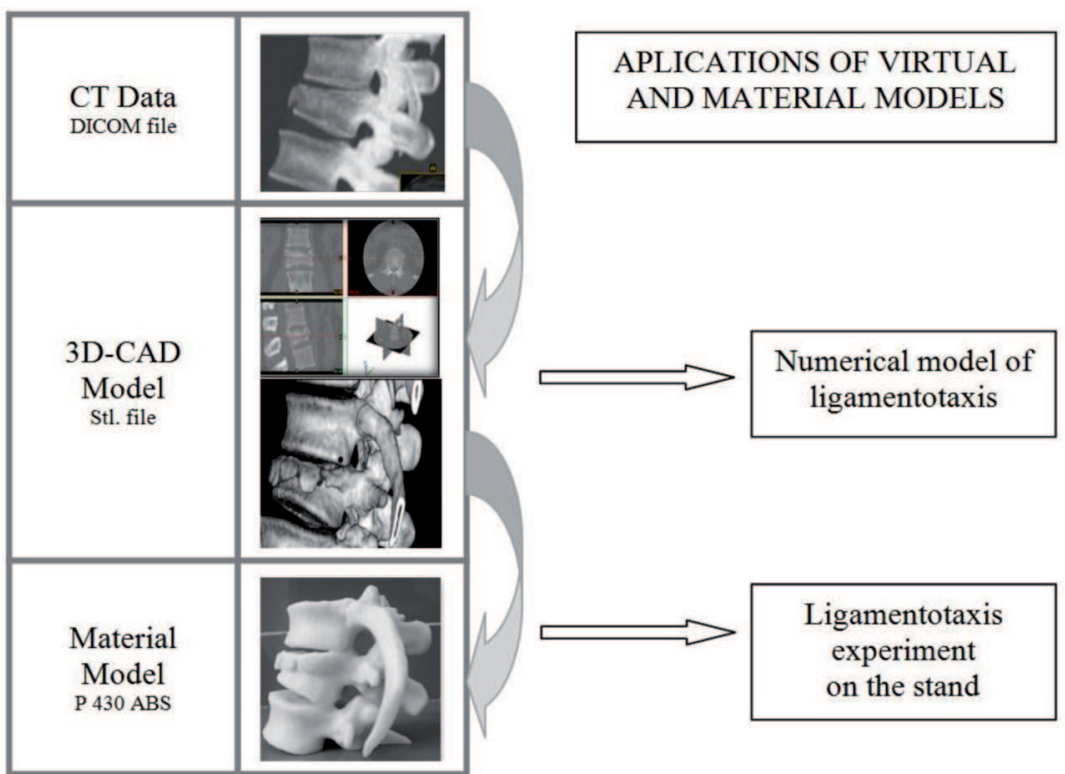

Fig. 1. Scheme of the building process and applications of 3D-CAD virtual and RP material models basing on CT data

\subsection{The building process of $3 D-C A D$ models}

The procedure of developing a 3D-CAD model based on CT data has been presented in the form of flowchart shown in Fig. 2. The first part of the procedure deals with CT images processing that consists in cutting off the area of bone structure from the other tissues. The interesting part of the processed CT data; i.e., bone structure of vertebral segment, is transferred to further processing [36], which consists in verification of the obtained surface model having the form of triangle mesh, in terms of deleting bad triangles, self-intersecting triangles, limiting the number of triangles and smoothing the surface. The process is continued until a satisfactory 3D-CAD model is obtained and then stored in the .stl format. 


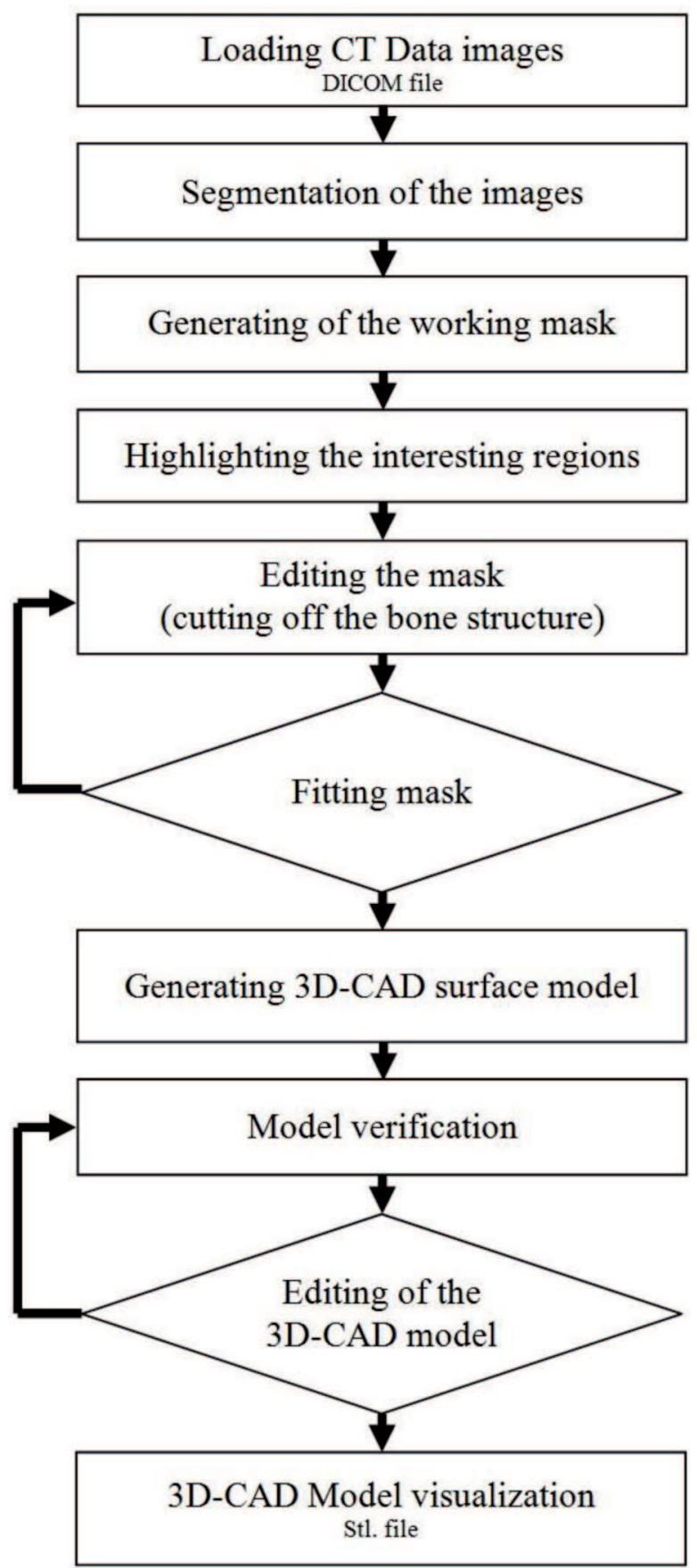

Fig. 2. Flowchart of the development process of 3D-CAD model the bone segment based on CT data made in the special software 
The models obtained in the way presented above are prepared for further applications, like numerical simulation of the relocation procedure and stabilization of a spine fragment, and then to building models based on its material by means of the RP technique.

\subsection{The building process of material models using the rapid prototyping (RP) technique}

The material models of the considered spine segments were built using fused deposition modeling (FDM) technology [37] with two materials: the material model (thermoplastic polimer ABSplus (P430 ABS)), and the support material (polymer based on organic compounds - soluble support technology SST). The material model building system comprises the Dimension Elite 1200 device (Stratasys Co.) supplied with PC computer and special software [35]. Additional element of the system consists in applying a device for washing off the support material. A sample pre-processing of the model building process is shown in Fig. 3.

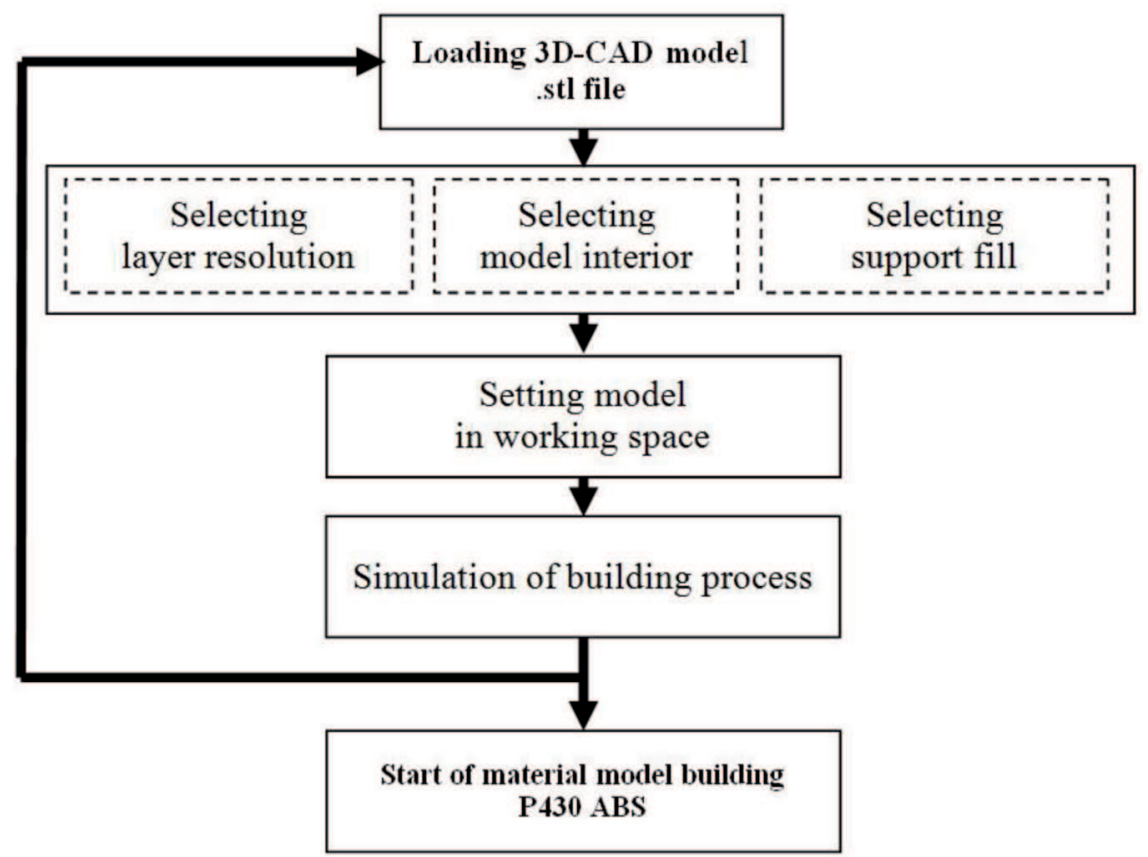

Fig. 3. Flowchart of pre-processing of the RP material model building process

The pre-processing parameters define the model structure in terms of defining the ways of building both the model and support materials. The limited working space of the device $(203 \times 203 \times 305 \mathrm{~mm})$ sometimes rises the necessity for dividing the model into its two parts. 
430 ANNA DĄBROWSKA-TKACZYK, ANNA FLORIAŃCZYK, ROMAN GRYGORUK, KONSTANTY SKALSKI, PIOTR BORKOWSKI

Basic parameters determining the material model structure consist of the layer resolution and model interior type, defined using the software [35]. The Dimension Elite 1200 device allows for choosing one of the following two layer resolutions: $0,178 \mathrm{~mm}$ or $0,254 \mathrm{~mm}$. The model interior type can be selected from among the following options: Solid, Sparse - high density, Sparse - low density (see Fig. 4). Selecting the option determines the stiffness and strength of the model, the amount of material used for building the model and the process time.
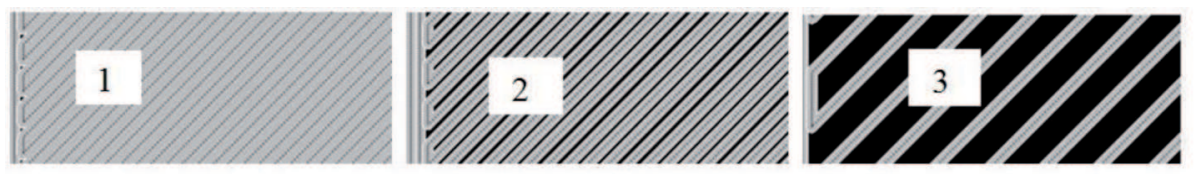

Fig. 4. The model interior type: 1 - Solid; 2 - Sparse - high density;

3 - Sparse - low density [35]

The support structures create the basic structure for the layers of model material depending on the orientation defined in the virtual device working space with the use of software [35]. The time necessary for the building process depends also on the support fill type, which can be selected from among the following options provided by the device applied: Basic, Sparse, Surround, Smart (see Fig. 5).

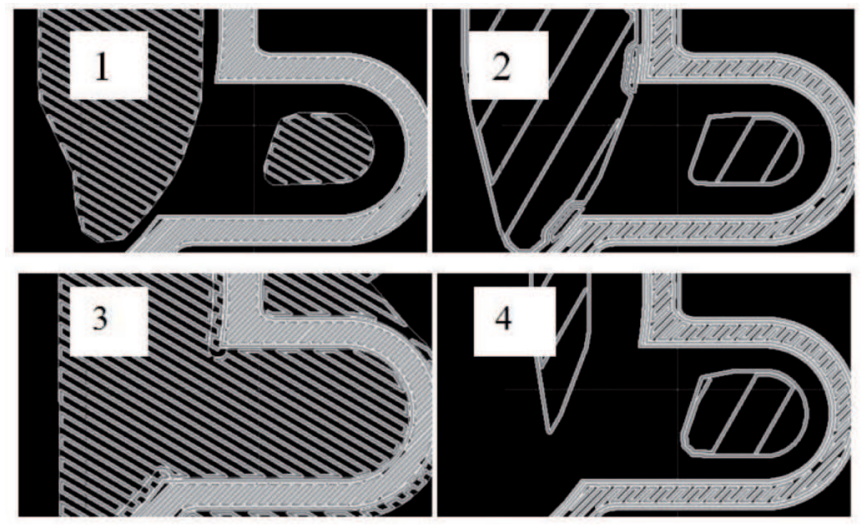

Fig. 5. The support fill types: 1 - Basic; 2 - Sparse; 3 - Surround; 4 - Smart [35]

At the present stage of investigations, the options of shortest time and lowest material consumption for building the model were selected. Six material models of human spine fragments were built following the procedure presented above. The following options were selected for all the models: 
- layer resolution -0,254 $\mathrm{mm}$,

- model interior - Sparse low density,

- support fill - Smart.

Most important phases of 3D-CAD model building process made in the software are shown in Fig. 6.

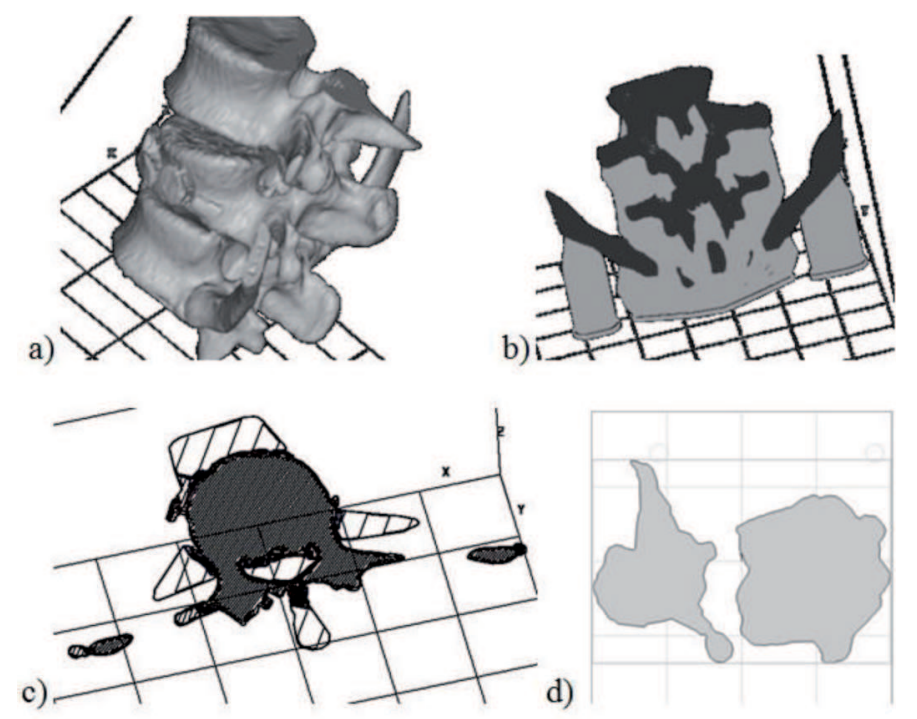

Fig. 6. Most important phases of RP material model building process, a) loaded .stl format of 3D-CAD model, b) the model with support structure, c) singular layer with its model and support structure, d) positions of the models in the virtual tray

\section{Results}

The results of investigations have the form of virtual 3D-CAD models and material models obtained using the procedures described above (in Fig. 2, 3 ), and also the material model of spine segment after stabilization with the applied USS Fracture system of implants [32].

\subsection{Virtual 3D-CAD models of spine fragments with fractured vertebra}

The CT data for five thoracic lumbar spine segments with fractured vertebra and one normal spine (for comparison reasons) have been processed, following the procedure shown in Fig.2, yielding 3D-CAD surface models stored in the .stl format. Both the geometry of segment and relative positions of vertebrae, and also the positions of pieces of the fractured vertebra were maintained as close to the images resulting from CT data and radiologists' comments as possible. The process of bone structure identification when 
building 3D-CAD models was supported by the data available in the literature on anatomy and radiology of human spine [3], [23], [27].

In medical practice, the crucial problem consists in proper classification of the clinical case since it determines the way of treatment (invasive, noninvasive), choice of an implant system and the corresponding instruments. The clinical cases we have analyzed, at the beginning, were classified using the 3D-CAD models. Therefore, the analyzed five clinical cases can be divided [14], [18] into the following groups: compression fracture with osteoporosis, compression fracture without osteoporosis changes, and rotation fracture. In clinical practice, complex cases are most common.

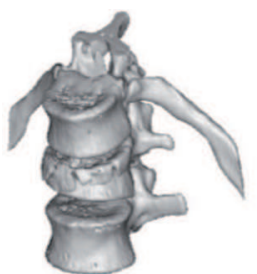

1

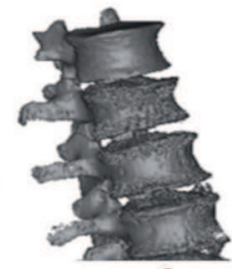

$\underline{2}$

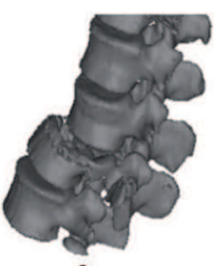

$\underline{3}$

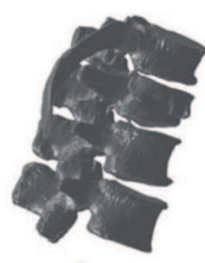

4

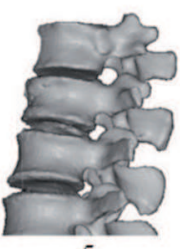

$\underline{5}$

Fig. 7. Sample fractures $-3 \mathrm{D}-\mathrm{CAD}$ models. The classification according to the Magerl A/O Spine standards: 1:L1-A 3.3, 2: L1-A 3.3, 3: L3-C3.1, 4:L1-A 2.3, 5: L1-A 2.1

More detailed classification has been made according to the Magerl/AO Spine standards [5], [21]. The results are briefly described in a shortened way in the caption below Fig. 7, where L1, L3 mean the numbers of broken lumbar vertebra, while A 3.3, C 3.1, A 2.3 and A 2.1 are the symbols of the fracture type according to the Magerl / AO Spine classification referring to the analyzed clinical cases.

\subsection{D-CAD model of normal spine}

The 3D-CAD model was developed including the bone tissues structure, and the selected soft tissues which were: anterior and posterior longitudinal ligaments (ALL, PLL) and intervertebral discs. In identification of the bone structures and geometrical model development of normal spine, the CT data on Th12- S1 fragment were used (Fig.8a), while more detailed models represented the segment Th12-L2 (Fig. 8b). The 3D-CAD model representing the segment was developed, in which the bone structures divided into cortical and trabecular bone tissue were considered as well as soft tissues (intervertebral disc, ligaments). The 3D-CAD model of bone tissues structure (Fig. 8.b) shows the investigation prospects in view of the properties of cortical and trabecular bone tissues in the developed numerical model [11], [10], [12]. Fig. 8c presents the model of segment Th12 -L2 with bone structures, 
ligaments ALL and PLL and intervertebral discs. This type of model will be used for numerical simulations of the relocation procedure in the spine segment with fractured vertebra.

a)

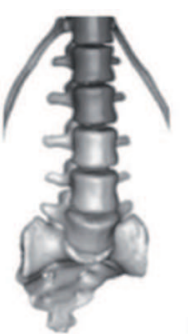

b)

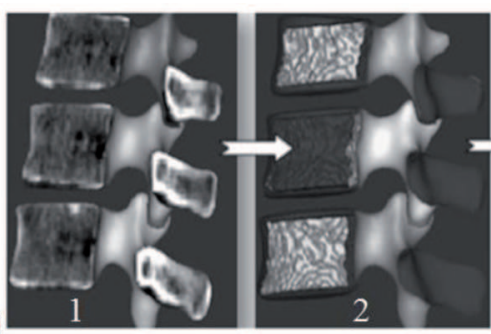

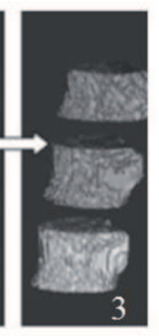

c)

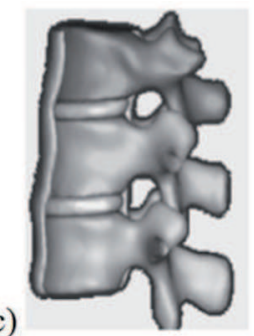

Fig. 8. 3D-CAD model of normal spine (G.M.): a) Th12-S1 fragment, b) considered segment Th12-L2: 1 - cross-section through bone structures of vertebral bodies, 2 - division into cortical and trabecular bone tissues, 3 - trabecular bone separated from the model, c) Th12-L2 segment model with soft tissues

\subsection{Material models build using the RP technique}

As it was stated above, 3D-CAD models of spine fragments paved the way for the corresponding material models made with the use of RP-FDM technology. Sample process of material model development for P.A. patient (of Th11 - S1 spine segment) is shown in Fig. 9. In the considered case, the model was divided into two anatomical parts: Th11 - L1 and L2 - S1, to fit the dimensions of parts of the model to working space of the Dimension Elite 1200 device.

Table 1.

Parameters of the material model building process made with the use of Dimension Elite 1200 device

\begin{tabular}{|c|c|c|c|c|}
\hline No. & Patient name & Model building time & Model material $\left[\mathrm{cm}^{3}\right]$ & Support material $\left[\mathrm{cm}^{3}\right]$ \\
\hline 1. & O.A. & 19h 56min & 185.51 & 48.05 \\
\hline 2. & S.M. & $60 \mathrm{~h} 56 \mathrm{~min}$ & 468.80 & 160.61 \\
\hline 3. & P.A. & $66 \mathrm{~h} 32 \mathrm{~min}$ & 372.14 & 196.18 \\
\hline 4. & S.K. & $81 \mathrm{~h} 5 \mathrm{~min}$ & 506.91 & 763.23 \\
\hline 5. & G.T. & 56h 5min & 448.84 & 136.51 \\
\hline 6. & G.M. & 49h $19 \mathrm{~min}$ & 414.68 & 142.92 \\
\hline
\end{tabular}

Table 1 presents details of the material model building process, (see Fig. 10.) and its characteristic parameters like model building time, amounts of the model and support materials used. These parameters depend on the 

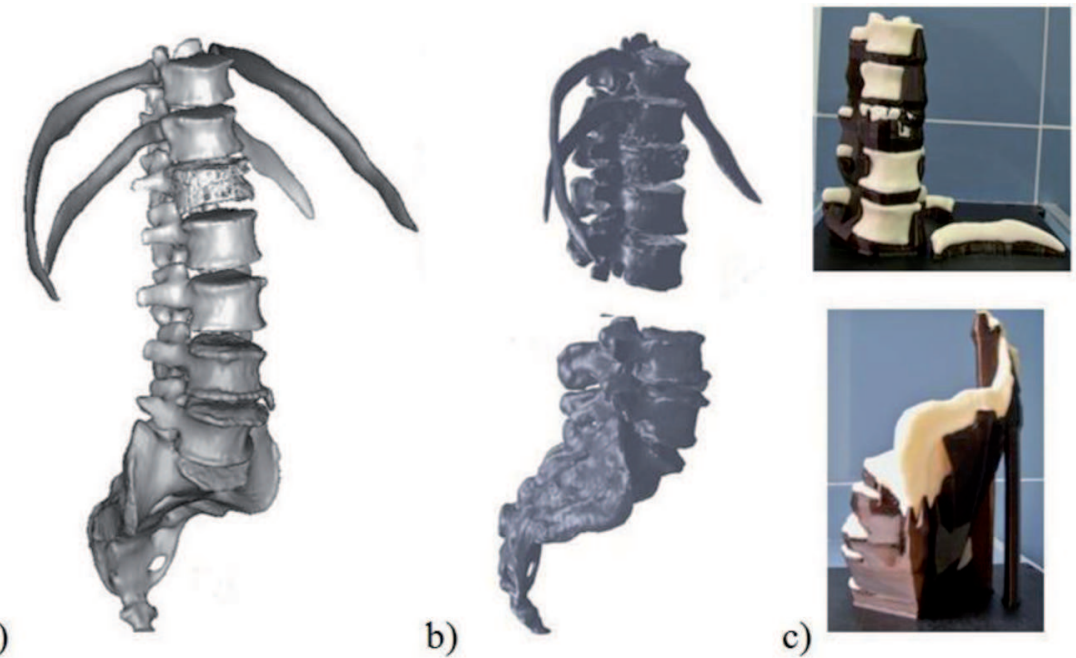

b)
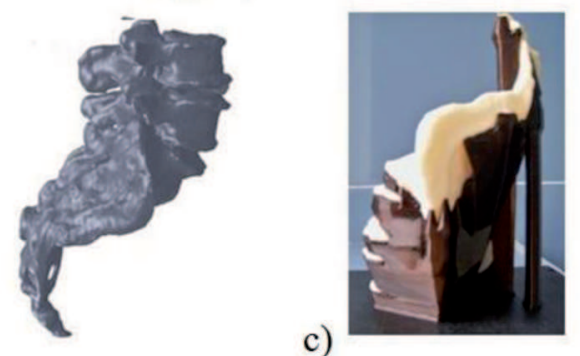

c)

Fig. 9. The process of material model development of P.A. patient. Th11-S1 fragment made using the RP technique: a) 3D-CAD model based on CT data, b) 3D-CAD model divided into two anatomical parts, prepared to material model building, c) material model parts with the support material structure

pre-processing assumptions made for the models and its supporting structures. After completing the building procedure, the final material models, consisting of separated vertebrae, were mounted on special stands, in the form convenient for presentation. The group of models shown in Fig. 10. comprises five models with fractured vertebra and the last one for normal spine segment.

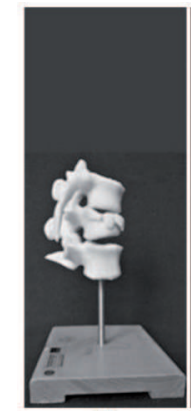

1)

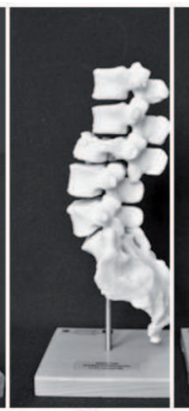

2)

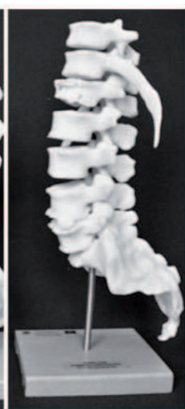

3)

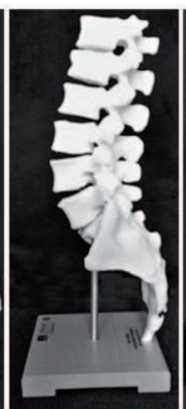

4)

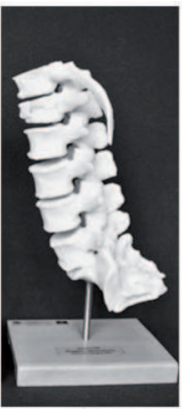

5)

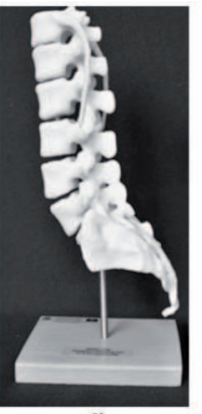

6)

Fig. 10. Final material models for the patients:

1 - O.A., 2 - S.M., 3 - P.A., 4 - S.K., 5 - G.T., and one for the normal spine; 6 - G.M.

Additionally, the models of single fractured vertebra were built (Fig. 11.) for comparison between the cases. As it can be seen, a proper classification of the trauma is possible basing on the presented models. These models show the character of fracture and stenosis of the spinal canal area. 


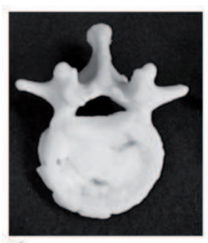

1)

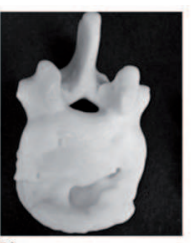

2)

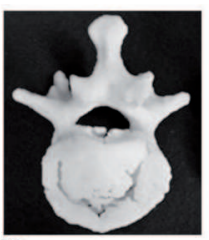

3)

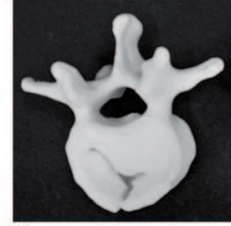

4)

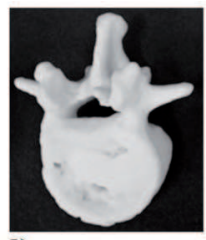

5)

Fig. 11. Material models of fractured vertebra of patients:

1 - O.A., 2 - S.M., 3 - P.A., 4 - S.K., 5 - G.T.

In Fig. 12. is shown the model [34] of Th12-L2 segment with compression fracture of the L1 vertebral body stabilized by the implant system [32].
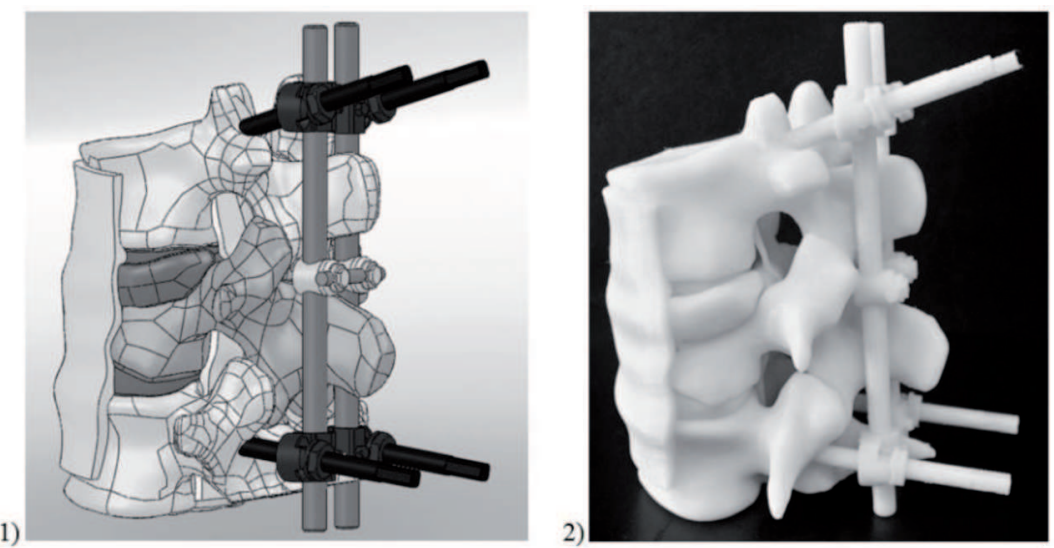

Fig. 12. Model of Th12-L2 segment with compression fracture of the L1 vertebral body stabilized by implant system: 1 - 3D-CAD model, 2 - material model

The results of conducted investigations have proved that material models made using the RP-FDM technology can be useful in analyzing bone structures at particular phases of the treatment process and are consistent with the results of other investigations in that area [28], [29], [30] since they represent adequately positions of vertebra relative each other and type of deformation: traumatic, osteoporosis, overload. The presented method was applied also to modeling a spine segment with fractured vertebra stabilized by an implant system [34].

\section{Discussion}

Medical imaging techniques, like X-ray, computer tomography CT, magnetic resonance imaging MRI [8], [18], [25] have been successfully applied in medical diagnostics and monitoring surgical procedures. For the purpose of identification of bone structures in orthopedics and traumatology, the 
436 ANNA DĄBROWSKA-TKACZYK, ANNA FLORIAŃCZYK, ROMAN GRYGORUK, KONSTANTY SKALSKI, PIOTR BORKOWSKI

X-ray and CT techniques are still most common [8], [22], [29]. The progress in computer image processing provided new prospects for 3D-CAD models of bone structures development, allowing for their assessment in view of surgery planning, and numerical simulations of surgery procedure with or without the implant systems [2], [4], [26], [28], [29], [30]. The CT technique is accurate enough in identification of bone structures of human spine. Most advances software used in the investigations allowed for accurate representation of fractured bone structures after trauma. It provided also the possibilities of determination of the type of fracture, comparison between different clinical cases, assessment of bone structure.

Basing on CT data and special software [36], one can also identify nonhomogeneous bone tissue (cortical and trabecular bone) and determine their constitutive properties [11], [10], [12]. More detailed model of the spine segment is shown on the example of normal spine, in which the bone tissue has been divided into cortical and trabecular, respectively, with the soft tissue included (intervertebral disc, and longitudinal ligaments). This model shows the investigation prospects in view of numerical modelling of spine segment with the strength analysis comprising material properties and loads acting in bone structures. The MRI is most common technique applied to soft tissue visualization [25]. In further investigations, it is planned to apply MRI data for creation more advanced and reliable model for simulation of broken spine segment relocation and stabilization procedure.

The RP techniques allow for effective representation of spine fragments or single vertebra using material models. The approach allows for observation and analysis of anatomical bone structures for a given clinical case. Therefore, the vertebra fractures can be identified according to chosen medical classification [14], [18], [22] in a more effective way. The material models made can be applied to presenting different types of fracture of thoracic-lumbar spine.

In further investigations the application of material models of human spine fragment with fractured vertebra (built using the RP technique) is planned to experimental simulation of reposition and stabilization surgery performed on a special measurement stand. To that end, models of implants and instruments should be developed as well. According to the above, material model building should be preceded by a 3D-CAD model development, therefore the two experiments of reposition and stabilization surgery; i.e., numerical and experimental may be performed parallel to one another. However, one should remember that the material model represents only the geometry of the modeled object. Conclusions from the experiment of animal spine, conducted before [9], as well as the developed virtual model of stabilization 
[34] will be helpful in development of research procedures, both experimental and numerical.

The material models of human spine fragments made for different medical cases can be applied not only by surgeons in surgery planning but also for educational purposes in the fields of medicine and bioengineering.

\section{Conclusions}

- The methods for CT data based visualization of spine segment bone structures in the form of 3D-CAD models and resulting material models using RP-FDM technology were presented in the paper.

- Sample models of five patients with broken spine and one normal spine were developed.

- Both virtual 3D-CAD models and RP-FDM material models may become a useful tool for supporting the pre-operative planning of relocation surgery of spine segment with broken vertebra.

- 3D-CAD virtual models and material RP-FDM materials models of single fractured vertebra allow for the assessment of fracture type and stenosis of the spinal canal area as well as for making more detailed classification according to medical standards.

- Virtual 3D-CAD modeling opens up the possibilities of development of more advanced numerical models in the purpose to perform the virtual relocation and stabilization procedure on the fractured spine segments using ligamentotaxis method.

- RP-FDM material models of fractured spine segment are planned to be applied in experimental simulations of the relocation and stabilization techniques on the a special stand.

\section{Acknowledgements}

The research was supported by the Polish Ministry of Science and Higher Education under grant no. N N518382437.

The clinical CT data on patients of Military Medical Institute (WIM) in Warsaw were employed for the purposes of the paper. According to Polish binding regulations the CT data transfer was agreed by the Bioethical Committee of WIM. 
438 ANNA DĄBROWSKA-TKACZYK, ANNA FLORIAŃCZYK, ROMAN GRYGORUK, KONSTANTY SKALSKI, PIOTR BORKOWSKI

\section{REFERENCES}

[1] Antonacci M., Eismont F.: Neurologic complications after lumbar spine surgery, J Am. Academy Ortop. Surg., 2001, vol. 9, no. 2, 137-145.

[2] Bibb R., Thompson D., Winder J.: Computed tomography characterization of additive manufacturing materials, Medical Engineering \& Physics, 2011, vol. 33, 590-596.

[3] Bochenek A., Reicher M.: Anatomia człowieka, Tom I, Wydawnictwo Lekarskie PZWL, Warszawa, 2007.

[4] Borkowski P.: Badanie i ocena funkcjonalności nowej konstrukcji endoprotezy wydłużalnej dla pacjentów dorastających, Rozprawa doktorska, Politechnika Warszawska, 2009.

[5] Chapman J.R., Dettori J.R., Norvell D.C.: Spine Classifications and Severity Measures, AOSpine International, Thieme, 2009.

[6] Chlebus E.: Innowacyjne technologie rapid prototyping - rapid tooling w rozwoju produkt, Oficyna wydawnicza Politechniki Wrocławskiej, Wrocław, 2003.

[7] Chua C. K., Leong K.F., Lim C.S.: Rapid Prototyping: Principles and Applications, 3rd edition, World Scientific Publishing Company, 2010.

[8] Cierniak R.: Tomografia komputerowa. Budowa urządzeń CT. Algorytmy rekonstrukcyjne, Akademicka Oficyna Wydawnicza EXIT, Warszawa 2005.

[9] Dąbrowska Tkaczyk A., Floriańczyk A., Skalski K., Kwiatkowski K., Cejmer W.: A surgery simulation of fractured vertebral body relocation on segment of animal spine, Acta of Bioengineering and Biomechanics, 2011 (in redaction).

[10] Dąbrowska-Tkaczyk A.: Evaluation Method for orthotropic properties of the bone tissue "in situ", Proc. Of 36th Solid Mechanics Conference, Gdańsk, 2008, 2p.

[11] Dabrowska-Tkaczyk A., Pawlikowski M.: Influence of remodeling stimulating factor selection on bone density distribution in pelvic bone model, Acta of Bioengineering and Biomechanics, 2006, vol. 8, no. 2,119-126.

[12] Dabrowska-Tkaczyk A., Domański J., Lindemann Z., Pawlikowski M., Skalski K.: Stress and strain distributions in the bones of hip joint assuming non-homogenous bone material properties, Proc. of II Int. Conf. on Computational Bioengineering 2005, vol. 2, 263-275.

[13] De Castro I.J.C., Shimano A.C., Bellucci A.D., Defino H.L.A.: Experimental study of ligamentotaxis maneuvers sequencing in vertebral canal decompression, Acta Orthopédica Brasileira, 2008, vol. 16, no. 5, 291-295.

[14] Denis F.: The three column spine and its significance in the classification of acute thoracolumbar spine injuries, Spine 8, 1983, 817.

[15] Esses SI., Sachs BL., Dreyzin V.: Complications associated with the technique of pedicle screw fixation. A selected survey of ABS members 1993, Spine, 2231-2238.

[16] Gebhardt A.: Generative Fertigungsverfahren. Rapid Prototyping - Rapid Tooling - Rapid Manufactooring, Hanser Fachbuch, 2007.

[17] Gibson I., Stucker B., Rosen D.: Additive Manufacturing Technologies: Rapid Prototyping to Direct Digital Manufacturing, Springer, 2009.

[18] Holdsworth F. Fractures: Dislocations, and fractures-dislocations of the Spine, J Bone Join Surg, vol. 52-A, no. 8, 1970, 1534-1551.

[19] Jun-Hong Min, Jee-Soo Jang, Seok-Kang Kim, Dae Hyeon Maeng, Sang-Ho Lee: The ligamentotactic effect on a herniated disc at the level adjacent to the anterior lumbar interbody fusion: report of two cases, J Korean Neurosurg Soc, 2009, vol. 46, 65-67.

[20] Lonstein J., Denis F., Perra J., Pinto M., Smith M., Wine R.: Complications associated with pedicle screws, J Bone Joint Surg (Am), 1999, vol. 81A, no. 11, 1519-1528.

[21] Magerl F., Aebi M., Gertzbein S.D., Harms J., Nazarian S.: Comprehensive Classification of Thoracic and Lumbar Injuries, Eur Spine Journal, 1994, J3:184-201.

[22] McAfee P., Yuan HA, Fredrickson BE, Lubicky JP.: The value of computed tomography in thoracolumbar fractures, J Bone Jonit Surg, vol. 65-A, no. 4, 1983, 461-473. 
[23] McMinn: Fotograficzny atlas anatomii człowieka, Wydawnictwo Medyczne Urban\&Partner, Wrocław, 2006.

[24] Mueller L.A., Mueller L.P., Schmidt R., Forst R., Ruding L.: The phenomenom and efficiency of ligamentotaxis after dorsal stabilization of thoracolumbar burst fractures, 2006.

[25] Rhin A.F., Yang N., Fisher Ch., Saravanja D., Smith H., Morrison W.B., Harrop J., Vaccaro A.R.: Using magnetic resonance imaging to accurately assess injury to the posterior ligamentous complex of the spine: a prospective comparison of the surgeon and radiologist, $\mathrm{J}$. Neurosurg. Spine, 2010, vol. 12, 391-396.

[26] Rohlmann A., Gabel U., Graichen F., Bender A., Bergmann G.: An instrumented implant for vertebral body replacement that measures loads in the anterior spinal column, Med. Eng. Phys., 2007, vol. 29, no. 5.

[27] Schwartz T.D., Reisdorff E.J.: Radiologia wypadkowa, Wydawnictwo CZELEJ Sp. z o.o., Lublin, 2002.

[28] Skalski K., Bossak M., Granowski R., Werner A.: Zastosowanie wirtualnego i szybkiego prototypowania w procesie projektowania endoprotez dopasowanych, Materiały IV FrancuskoPolskiego Seminarium Naukowego „Modelowanie i Symulacja Układów Fizycznych i Struktur Technicznych", Warszawa, 1999, Politechnika Warszawska - Universite des Science et Technologies de Lille, 21-33.

[29] Skalski K., Haraburda M, Bossak M., Kędzior K., Smolik W.: Ocena alloplastyki stawu biodrowego poprzez szybkie prototypy stereolitograficzne kości i endoprotez, I Krakowskie Warsztaty Inżynierii Medycznej, 18-19.05.2000r., Instytut Mechaniki i Podstaw Konstrukcji Maszyn, Kraków 2000, 147-153.

[30] Skoworodko J.: Metodyka projektowania implantu międzykręgowego kręgosłupa lędźwiowego. Rozprawa doktorska, Politechnika Warszawska, Wydział Inżynierii Produkcji, 2008.

[31] Steffe AD., Brantigan JW.: The variable screw placement spinal fixation system. Report of a prospective study 250 patients enrolled in Food and Drug Administraction clinical trials. 1993, Spine 18 1160-1172.

[32] USS Fracture System Original Instruments and implants of the Association for the Study of Internal Fixation - AO/ASIF.

[33] Yamauchi T., Yamazaki M., Okawa A., Furuya T., Hayashi K., Sakuma T., Takahashi H., Yanagawa N, Koda M.: Efficacy and reliability of highly functional open source DICOM software (OsiriX) in spine surgery, Journal of Clinical Neuroscience, 2010, vol. 17, 756-759.

[34] Zięba Ł.,Dąbrowska-Tkaczyk A.: Wirtualna stabilizacja kręgosłupa człowieka po złamaniu kompresyjnym na odcinku piersiowo-lędźwiowym. Aktualne Problemy Biomechaniki, Politechnika Śląska, Zeszyty Naukowe Katedry Mechaniki Stosowanej, z. 5, Gliwice 2011, 189-194.

[35] CatalystEX® Pomoc programu.

[36] www.materialise.com (2011).

[37] www.stratasys.com (2011).

Modelowanie wirtualne i materialne złamań kompresyjnych odcinka piersiowo-lędźwiowego kręgosłupa pacjenta z wykorzystaniem danych CT oraz technologii szybkiego wytwarzania prototypów

$$
\text { Streszczenie }
$$

W pracy zostały przedstawione procedury opracowania modeli wirtualnych i materialnych uszkodzonych, w efekcie urazów lub długotrwałej patologii, odcinków kręgosłupa pacjentów oraz 
przykłady wykonanych modeli. Przedstawione w pracy modele wirtualne opracowano na podstawie danych CT pięciu pacjentów oraz jednego przypadku odcinka kręgosłupa prawidłowego. Tworzona jest tym samym baza danych modeli segmentów kręgosłupa piersiowo-lędźwiowego z jednym trzonem złamanym kompresyjnie dla wybranej klasy przypadków klinicznych. Modele te posłużyły następnie do wykonania ich odpowiedników materialnych w technice szybkiego wytwarzania prototypów (rapid rototyping - RP). Zastosowana została technologia FDM (fused deposition modeling). Wizualizacja segmentów lub odcinków kręgosłupa poprzez tworzenie modeli wirtualnych i materialnych daje możliwość analizy struktur kostnych, klasyfikacji i oceny przypadków oraz rozważenie możliwych wariantów leczenia urazu. Przewiduje się wykorzystanie opracowanych modeli do przeprowadzenia numerycznej oraz doświadczalnej symulacji nastawiania odłamów złamanego trzonu. Praca jest częścią realizacji projektu dotyczącego procedur leczenia, nastawiania i stabilizacji złamanego trzonu kręgu metodą ligamentotaksji. 